\title{
Review Article \\ Potential Benefits of Jujube (Zizyphus Lotus L.) Bioactive Compounds for Nutrition and Health
}

\author{
Souleymane Abdoul-Azize \\ Department of Pharmacy, Research Group "Integrated Cellular Renewal and Microenvironment", MERCI UPRES EA 3829, \\ University of Rouen, 76183 Rouen Cedex, France
}

Correspondence should be addressed to Souleymane Abdoul-Azize; souleymane.abdoul-azize@univ-rouen.fr

Received 13 July 2016; Accepted 23 October 2016

Academic Editor: C. S. Johnston

Copyright (C) 2016 Souleymane Abdoul-Azize. This is an open access article distributed under the Creative Commons Attribution License, which permits unrestricted use, distribution, and reproduction in any medium, provided the original work is properly cited.

\begin{abstract}
Zizyphus lotus, belonging to the Rhamnaceae family, is a deciduous shrub which generally grows in arid and semiarid regions of the globe. In traditional medicine, $Z$. lotus is used as antidiabetes, sedative, bronchitis, and antidiarrhea by local populations. Recently, several scientific reports for health benefit and nutritional potential of bioactive compounds from this jujube have been reported. This plant is rich in polyphenols, cyclopeptide alkaloids, dammarane saponins, vitamins, minerals, amino acids, and polyunsaturated fatty acids. These identified compounds were supposed to be responsible for most of $Z$. lotus biologically relevant activities including antimicrobial, anti-inflammatory, hypoglycemic, antioxidant, and immunomodulatory effects. The aim of the present review was to give particular emphasis on the most recent findings on biological effects of the major groups of Zizyphus lotus components and their medical interest, notably for human nutrition, health benefit, and therapeutic impacts.
\end{abstract}

\section{Introduction}

Zizyphus Lotus (Z. Lotus), also known as jujube, belongs to the angiosperm Rhamnaceae family. This family includes about 135-170 species of Zizyphus [1]. As a tropical and subtropical plant, Z. Lotus grows generally in arid and semiarid countries and is widely distributed in China, Iran, Africa, South Korea, and Europe like Cyprus, Spain, Greece, and Sicily [2-4]. In Africa, Z. Lotus is widely distributed in Mediterranean region, like Algeria, Morocco, Tunisia, and Libya [5]. This plant is employed in nutrition, health, and cosmetics in several forms, for example, honey, tea, jam, juice, oil, loaf, and cake. In addition, in traditional medicine, both in North Africa and Middle East, several parts of Z. lotus are given as antiurinary troubles agents, antidiabetes, skin infections, antifever, antidiarrhea, insomnia agents, sedative, bronchitis, and hypoglycemic activities [6-9]. On the other hand, this plant offers a delicious read fruit (jujube) that was consumed fresh, dried, and processed as food by local populations in substantial amounts [10].
In recent years, several scientific reports have been carried out about the presence of many biologically active molecules from $Z$. lotus, which may have high potential benefit in human nutrition, health, and disease [11, 12]. In herbal medicine, the properties of bioactive compounds from plants depend on the part of the plant concerned (root, leaf stalk, pulp, or fruit) and the type of extract used. $Z$ lotus is known for its high content in polyphenols exhibiting antioxidant and antimicrobial, immunomodulatory properties [13, 14]. Importantly, others biologically active molecules, particularly cyclopeptide alkaloids, termed lotusines [15-17], dammarane saponins [12], and various flavonoids [18] have been isolated from this shrub, along with polyunsaturated fatty acids (oleic acid and linoleic acid), high carbohydrate, and fibers which are abundant in seed extracts and endowed with antiulcerogenic and antioxidants effects $[11,19]$.

This review is devoted to the most recent findings on biological effects of the major compounds isolated from different parts of $Z$. lotus and to the different usages of this plant in human foods, health promoting, and disease prevention. 


\section{General Compound Content of Z. lotus}

Z. lotus fruit contains substantial amounts of glutamic acid, mineral matter, sterols, vitamins, tocopherols, fibers, amino acids, triacylglycerol, fatty acid, carbohydrate, and antioxidant compounds (phenols, flavonoids, etc.) which have been supposed to be responsible for most of its health benefits such as hypoglycemic, gastroprotective, immunomodulatory, and antioxidant properties $[14,21,22]$. In this respect, the fruit of $Z$. lotus is a valuable source of nutrients as well as antioxidant $[4,21,23,24]$, antimicrobial, and antifungal $[13,25]$, immunosuppressive [14], anti-inflammatory [26], and antiulcerogenic $[21,27]$ compounds. $Z$. lotus leaves contain different carbohydrates and dammarane saponins notably jujuboside $\mathrm{B}$, three jujubogenin glycosides, and jujubasaponine IV [20]. Z. lotus seeds are used to prepare lotus oil enriched in essential fatty acids, liposoluble antioxidants, and many sterols [11]. Z. lotus root contains four dammarane saponins, large quantity of polyphenol, essential fatty acids, vitamin C, and several cyclopeptide alkaloids, termed lotusines which have a wide range of pharmacological activities including antioxidant, antiproliferative, and antidiabetic activities [12, 15-18, 22, 24, 28]. The pulp of $Z$. lotus contains a significant amount of carbohydrate, phenols, flavonoids, and tannins, which exhibit high antimicrobial activity $[19,25]$.

\section{Classification of Natural Biomolecules of Z. lotus}

As a source of polyphenols, fatty acids, vitamins, and other natural compounds, $Z$. lotus seems to be a potential candidate for human nutrition, health promoting, and disease preventing. An overview of bioactive compounds for each part of $Z$. lotus is presented thereafter.

3.1. Major Compounds including Phenols, Flavonoids, Alkaloids, Saponins, and Other Biomolecules. Plant-derived polyphenols are a family of organic molecules. During the last decade, there has been a growing interest in the role of polyphenols, in several human pathologies. They have been shown to possess cardioprotective [30], anticancer, antiviral, antiallergenic, and antispasmodic properties [31, 32]. Given their chemical structure characterized by the presence of many phenolic groups, polyphenols are also able to scavenge reactive radical species and prevent peroxidative reactions [33]. Numerous studies showed their ability to prevent damage of lipids, proteins, and nucleic acids by reactive oxygen and nitrogen species [34-36] and modulate transcription factors $[37,38]$ and protein tyrosine kinases activation $[39,40]$.

All parts of $Z$ lotus are rich in polyphenol family members such as flavonoids, phenolic acids, and other natural compounds (Table 1). In the fruit, total phenols are the major compound, amounting from 297 to $4078.2 \mathrm{mg} / 100 \mathrm{~g}$ of dry matter; in addition, flavonoids and tannins are present in moderate quantities, 122 and $33 \mathrm{mg} / 100 \mathrm{~g}$, respectively [13, 23]. In the leaf, total phenol content is $664 \mathrm{mg} / 100 \mathrm{~g}$ [13], along with flavonoids ranging from 130 to $199 \mathrm{mg} / 100 \mathrm{~g}$ [13, $18]$, high content of saponins (340 mg/100 g) [18], and large amount of carbohydrates $(8720 \mathrm{mg} / 100 \mathrm{~g}$ ) [20], and other molecules are found in small quantities under $10 \mathrm{mg} / 100 \mathrm{~g}$ (see Table 1). Interestingly, Z. lotus seeds contain a very high amount of several compounds such as fats $(29.73 \mathrm{~g} / 100 \mathrm{~g})$, fibers $(16.57 \mathrm{~g} / 100 \mathrm{~g})$, and protein $(14.22 \mathrm{~g} / 100 \mathrm{~g})$ [19], along with carbohydrates $(4720 \mathrm{mg} / 100 \mathrm{~g})$ and small amounts of polyphenol $(14.68 \mathrm{mg} / 100 \mathrm{~g})$ [11]. In Z. lotus root bark, polyphenol content is $2009 \mathrm{mg} / 100 \mathrm{~g}$ [24], along with a high content of saponins $219 \mathrm{mg} / 100 \mathrm{~g}$, high content of flavonoids (120 mg/100 g) [18], and large amount of proanthocyanidins (156 mg/100 g) [24] compared to other molecules such as cyclopeptide alkaloids, amounting from 1.4 to $23.95 \mathrm{mg} / 100 \mathrm{~g}$ [15-17] (Table 1). Z. lotus pulp contains high amounts of soluble sugars $(10.55 \mathrm{~g} / 100 \mathrm{~g})$, fibers $(4.84 \mathrm{~g} / 100 \mathrm{~g})$, mineral matter $(3.2 \mathrm{~g} / 100 \mathrm{~g})$, and protein $(1.18 \mathrm{~g} / 100 \mathrm{~g})$ [19], along with tannins $(922 \mathrm{mg} / 100 \mathrm{~g})$ and moderate amounts of polyphenol (325 mg/100 g) [25].

In summary, aerial parts (leaves and fruits) of $Z$. lotus are the most important source of polyphenols and flavonoids (3630-8144 mg/100 g) [26], while the seeds are rich in fats [19]. These variations in $Z$. lotus biomolecules content might be due to the environment, soil type, climate, or age of the plant.

It should be noted that the biological activities of $Z$. lotus are allocated to the different classes of pharmacologically active compounds such as flavonoids, several saponins, and alkaloids (Table 1). It has been reported that $Z$. lotus alkaloids exerted significant antifungal and antibacterial properties $[12,17]$. Z. lotus saponins presented antisweet effects [12]. Currently, seven alkaloids (called lotusines, named from A to $G$ ) and nine saponins (seven jujubogenins and two lotogenins) (Figure 1 and Table 1) have been isolated from this plant, and the main chemical compounds including lotusine A, lotusine $B$, lotusine $C$, jujuboside $A$, lotoside $I$, and 3O- $\alpha$-L-rhamnopyranosyl-(1-2)-[(4-sulfo)- $\beta$-Dglucopyranosyl-(1-3)]- $\alpha$-L-arabino-pyranosyl-jujubogenin are presented in Figure 2.

3.2. Z. lotus Fatty Acid Composition. The analysis of lipid composition showed that Z. lotus pulp (Table 1) was rich in palmitic acid (C16:0), oleic acid (C18:1), and linoleic acid (C18:2), amounting to $27.59 \%, 24.52 \%$, and $36.63 \%$ of total fatty acid content, respectively (Table 2) [28]. Linoleic acid is considered as essential fatty acids. Its content in $Z$. lotus pulp $(36.87 \%)$ is thus close to the amount found in olive oil (1.1\%) [41] and argan oil (31.3\%) [42] but lower to the percentage found in soybean oil (50.1\%) [43] and corn oil (56\%) [44] (Table 2).

Numerous studies reported that all parts of $Z$. lotus particularly, seeds, pulp, fruits, leaves, almond, root, and stem, were rich in palmitic, stearic, linoleic, and oleic acid $[11,13,19,28]$. Oleic acid was the most important fatty acid of $Z$. lotus fruits [13], seeds [11], and almond [19] at $88.12 \%$, $61.93 \%$, and $49.88 \%$, respectively. In vivo studies in rabbit LDL model provided evidence that oleic acid is responsible of the potent antioxidant properties attributed to many edible oils rich in this fatty acid [45]. Moreover, it has been reported that oleic acid upregulated the expression of breast cancer resistance protein and thereby modulates intestinal retention 
TABLE 1: Distribution and contents of major bioactive compounds including phenols, flavonoids, alkaloids, saponins, and other phytochemicals in the various parts of $Z$. lotus.

\begin{tabular}{|c|c|c|c|}
\hline Z. lotus part & Major component & Content in $\mathrm{mg} / 100 \mathrm{~g}$ & Authors \\
\hline \multirow{3}{*}{ Fruit } & Total phenolic acid & $297-4078.2$ & \multirow{3}{*}[13,23]{} \\
\hline & Flavonoids & 122 & \\
\hline & Tannins & 33 & \\
\hline \multirow{11}{*}{ Leaf } & Total phenolic & 664 & \multirow{11}{*}[13,18,20,29]{} \\
\hline & Flavonoids & $130-199$ & \\
\hline & Tannins & 39 & \\
\hline & Saponins & 340 & \\
\hline & Jujuboside B & 3 & \\
\hline & 3 jujubogenin glycosides & 9.33 & \\
\hline & Jujubasaponin IV & 2 & \\
\hline & Monosaccharides (glucose, galactose, rhamnose, arabinose, and xylose) & 8720 & \\
\hline & Flavonol glycoside & 3 & \\
\hline & Rutin & 3.66 & \\
\hline & $3^{\prime}, 5^{\prime}$-Diglucosylphloretin & 3 & \\
\hline \multirow{7}{*}{ Seed } & Total carbohydrate & 4087 & \multirow{7}{*}[11,19]{} \\
\hline & Polyphenol & 14.68 & \\
\hline & Crud fats & 29730 & \\
\hline & Soluble sugars & 4100 & \\
\hline & Total fibres & 16570 & \\
\hline & Pectins & 1350 & \\
\hline & Crud protein & 14220 & \\
\hline \multirow{15}{*}{ Root bark } & Total flavonoids & 120 & \multirow{15}{*}[12,15-18,24]{} \\
\hline & Saponins & 219 & \\
\hline & Jujuboside A & 6.73 & \\
\hline & Jujuboside C & 3.96 & \\
\hline & Lotoside I & 2.774 & \\
\hline & Lotoside II & 1.58 & \\
\hline & Lotusine A & 11.56 & \\
\hline & Lotusine B & 23.95 & \\
\hline & Lotusine C & 23.95 & \\
\hline & Lotusine D & $4.2-10$ & \\
\hline & Lotusine E & $2.9-10$ & \\
\hline & Lotusine F & $1.4-11.56$ & \\
\hline & Lotusine G & 1.5 & \\
\hline & Polyphenol & 2009 & \\
\hline & Proanthocyanidins & 156 & \\
\hline \multirow{9}{*}{ Pulp } & Total phenols & 325 & \multirow{9}{*}[19,25]{} \\
\hline & Flavonoids & 173 & \\
\hline & Tannins & 922 & \\
\hline & Crud fats & 790 & \\
\hline & Soluble sugars & 10550 & \\
\hline & Total fibres & 4840 & \\
\hline & Pectins & 2070 & \\
\hline & Crud protein & 1180 & \\
\hline & Mineral matter & 3200 & \\
\hline
\end{tabular}




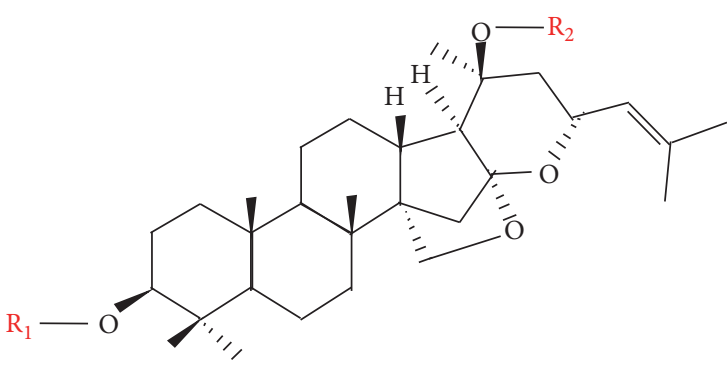

(a) $[12]$

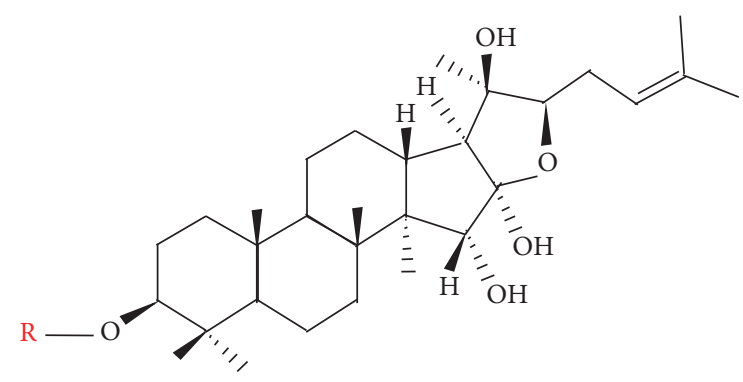

(b) $[12]$

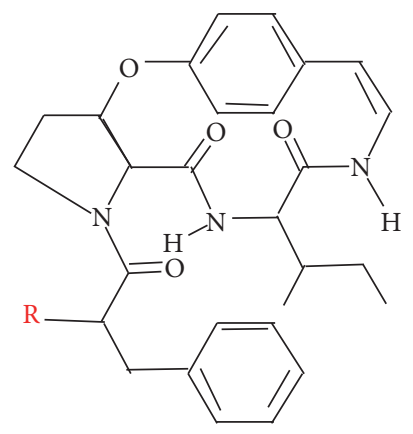

(c) [15]

FIGURE 1: Common structure of jujubogenins (a), lotogenins (b), and lotusines (c) found in Z. lotus [12, 15-17, 20].

of several food toxicants [46]. Z. lotus almond also presented moderate level of linoleic acid (22.97\%). This fatty acid is the precursor of arachidonic acid, which has inhibitory effect of colon cancer [47]. Other fatty acids were also present in this plant like linolenic acid (9.15\%) particularly in $Z$ lotus leaves. Linolenic acid is the precursor of docosahexaenoic acid, known to have potential benefit for health and for other diseases like cardiovascular diseases.

3.3. Triacylglycerol Composition of Z. lotus Seed Oil. Highperformance liquid chromatography (HPLC) analyses of triacylglycerol (TAG) composition show that $Z$ lotus seed oil contains several TAG (Table 3). The glycerol-trioleate was the most compound, amounting to $26.48 \mathrm{~g} / 100 \mathrm{~g}$, along with glycerol-palmitate-dioleate with $18.78 \mathrm{~g} / 100 \mathrm{~g}$ [11] (Table 3).

It has been shown that many types of TG like glyceroltrioleate, glycerol-palmitate-dioleate, glycerol-dioleatelinoleate, and glycerol-palmitate-oleate-linoleate stabilized oil oxidation $[56,57]$. Thus, $Z$. lotus seed represents a natural source of oil for food industry.

3.4. Vitamins Composition of Z. lotus. The pulp of Z. lotus is rich in vitamin $C$ in amounts up to $190.65 \mathrm{mg} / 100 \mathrm{~g}$, followed by $Z$. lotus seeds, leaves, root, and stem, containing 170.84 , $63.40,47.20$, and $24.65 \mathrm{mg} / 100 \mathrm{~g}$, respectively (Table 4$). Z$. lotus leaves content is high in vitamin E with $155.71 \mathrm{mg} / 100 \mathrm{~g}$ [28], while $Z$. lotus's seeds are enriched in $\beta$-tocopherols with $130.47 \mathrm{mg} / 100 \mathrm{~g}$ [11]. A little amount of carotenoids $(1.47 \mathrm{mg} / 100)$ was found only in $Z$. lotus fruits. Vitamins B1 and B2 were present in $Z$. lotus seeds with 0.03 and $0.08 \mathrm{mg} / 100 \mathrm{~g}$. Several parts of $Z$. lotus are rich in vitamin A, ranging from 3.8 to $71.63 \mathrm{mg} / 100 \mathrm{~g}$. Collectively, these data provide evidence that $Z$. lotus might be considered as a source of many vitamins for human food.

3.5. Sterols Composition of Z. lotus. Plant-derived sterols have been reported to decrease LDL cholesterol level in blood [58]. The quality of vegetable oil is correlated with its sterol contents. The sterol analysis of $Z$. lotus seed oil showed that seven compounds have been identified [11]. $\Delta^{7}$-Campesterol was the major compound with $147.82 \mathrm{mg} / 100 \mathrm{~g}$ (51.86\% of total sterol), along with $\beta$-sitosterol and campesterol with 82.10 and $31.89 \mathrm{mg} / 100 \mathrm{~g}$, respectively (Table 5). Other sterols notably stigmasterol, $\Delta^{5}$-avenasterol, $\Delta^{5}, 24$-stigmatadienol, and cholesterol are present in small quantities. Total sterols content in Z. lotus seed oil was $285.03 \mathrm{mg} / 100 \mathrm{~g}$. Compared to other vegetable oils, this content is better than $Z$. jujuba oil (18.56 mg/100 g) [10] and virgin oil (150 mg/100 g) [59] but lower than those measured in Z. zizyphus $(291.82 \mathrm{mg} / 100 \mathrm{~g}$ ) [54] and soy oil (350 mg/100 g) [60]. It is important to indicate that there is no available data on the sterol content in the other parts of $Z$. lotus; this issue remains to be determined.

3.6. Mineral Composition of Z. lotus. The mineral analysis of $Z$. lotus fruit showed that calcium, magnesium, and potassium were the predominance compounds with 490.84, 397.91, and $134.99 \mathrm{mg} / 100 \mathrm{~g}$, respectively, [55] (Table 6). Similar amounts for magnesium and calcium were found in $Z$. lotus pulp [19], while higher contents of these three minerals are present in $Z$. lotus seeds, with amounts ranging from 92.41 to $1349.06 \mathrm{mg} / 100 \mathrm{~g}[11,19]$.

3.7. Amino Acids Composition of $Z$. lotus. Amino acids composition of $Z$. lotus seeds shows that threonine is the 


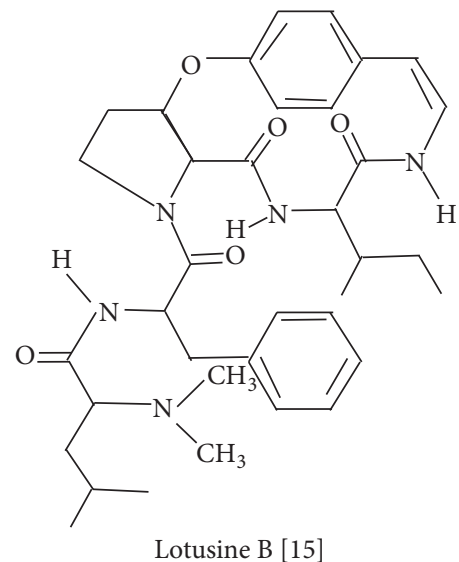

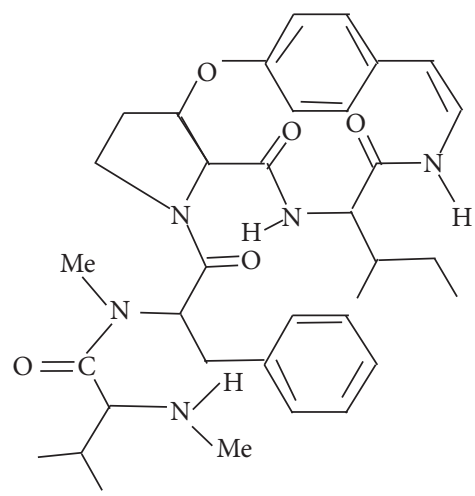

Lotusine C [16]

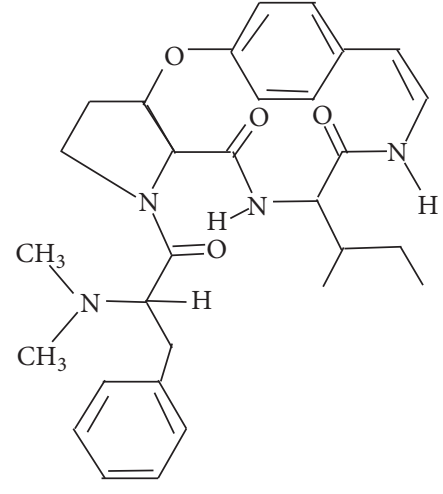

Lotusine A [15]

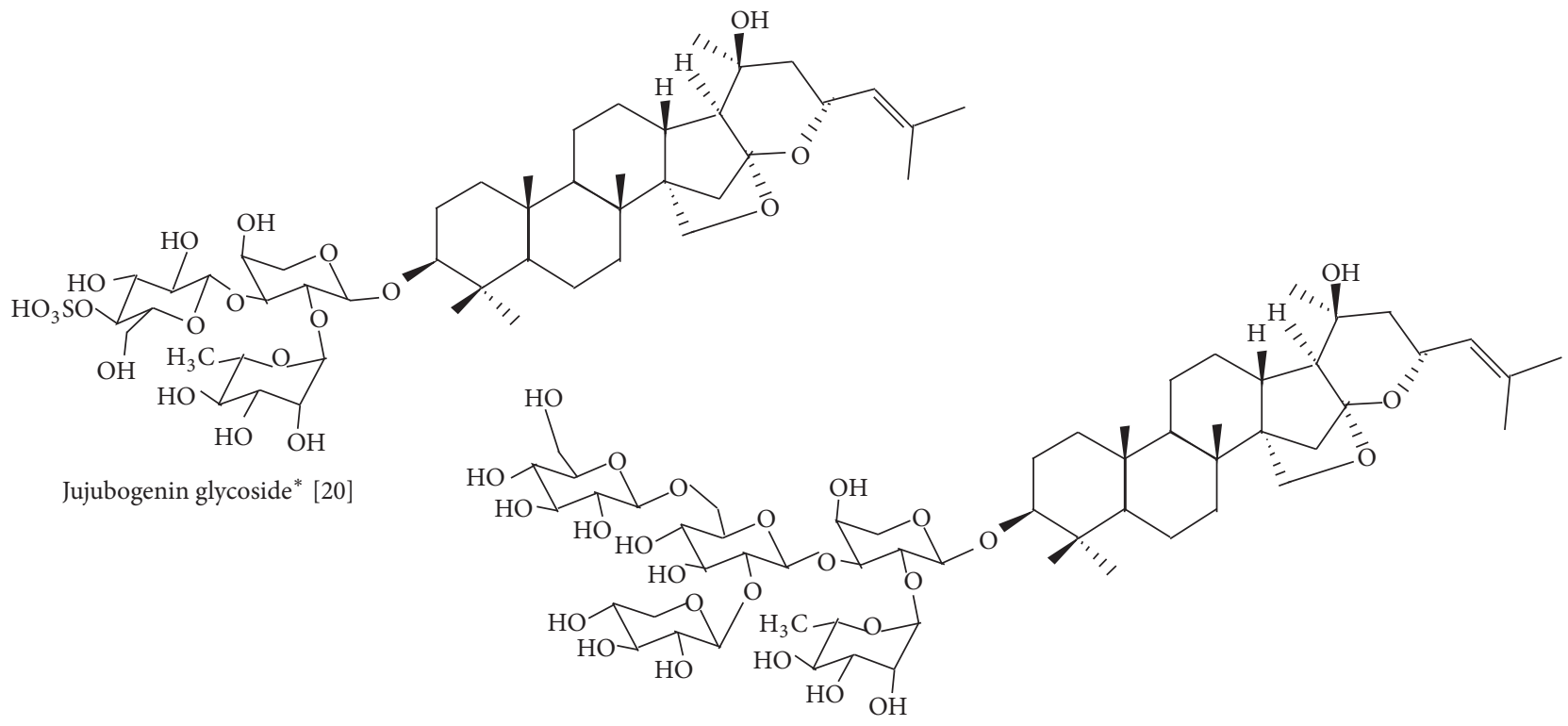

Jujuboside A [12]

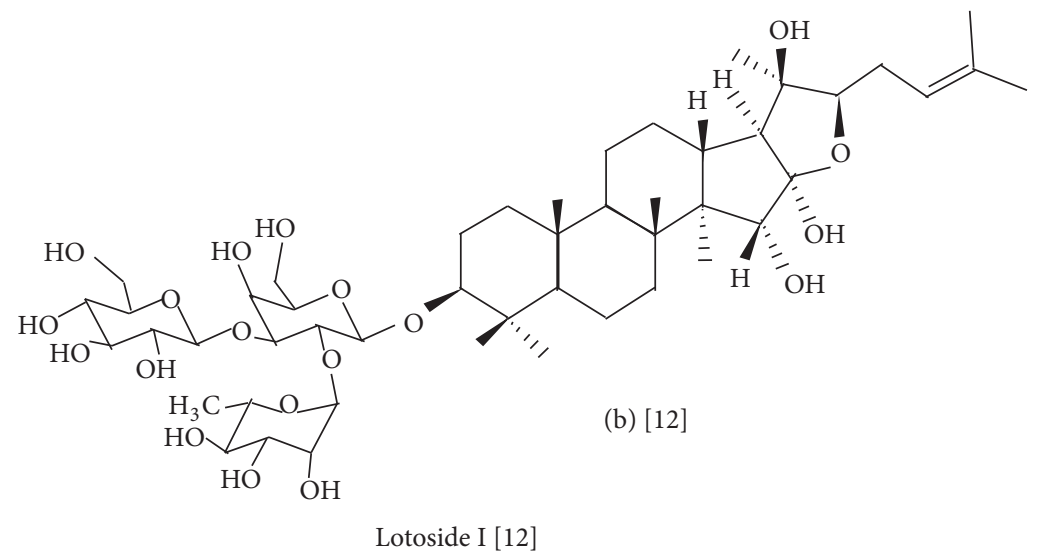

FIGURE 2: Structure of $Z$. lotus main phytoconstituents. Note: *3-O- $\alpha$-L-rhamnopyranosyl-(1-2)-[(4-sulfo)- $\beta$-Dglucopyranosyl-(1-3)]- $\alpha$-Larabinopyranosyl-jujubogenin. 
TABLE 2: Comparison of the fatty acid composition of $Z$. lotus and other edible oils; compositions are expressed in g/100 g fatty acids.

\begin{tabular}{|c|c|c|c|c|c|c|c|c|c|c|c|c|c|}
\hline Fatty acid & $\mathrm{C} 12: 0$ & C14:0 & $\mathrm{C} 16: 0$ & $\mathrm{C} 16: 1$ & $\mathrm{C} 18: 0$ & $\mathrm{C} 18: 1$ & $\mathrm{C} 18: 2$ & $\mathrm{C} 18: 3$ & C20:0 & C22:0 & $\mathrm{C} 22: 1$ & C24:0 & references \\
\hline Z. lotus seed oil & - & 0.06 & 9.14 & 0.13 & 4.84 & 61.93 & 18.31 & 1.35 & 0.17 & 0.73 & - & - & {$[11]$} \\
\hline Z. lotus seeds & - & 0.15 & 10.8 & 0.130 & 5.45 & 62.79 & 14.22 & 1.30 & 0.1 & - & - & 0.9 & {$[28]$} \\
\hline Z. lotus pulp & - & 0 & 27.59 & 0 & 11.25 & 24.52 & 36.63 & 0 & 0 & - & - & 0 & {$[28]$} \\
\hline Z. lotus fruits & 0.13 & 0.176 & 0.716 & - & - & 88.12 & 0.48 & 0.715 & 0.178 & 0.116 & 0.316 & - & {$[13]$} \\
\hline Z. lotus leaves & - & 0 & 43.41 & 5.96 & 22.15 & 6.30 & 6.20 & 9.15 & 0 & - & - & 1.54 & {$[28]$} \\
\hline Z. lotus almond oil & - & 0.084 & 9.025 & 0.134 & 7.106 & 49.88 & 22.97 & 0.409 & 2.367 & 1.409 & - & - & [19] \\
\hline Z. lotus root & - & 0 & 38.76 & 0 & 22.00 & 19.73 & 13.24 & 0 & 0 & - & - & 3.66 & {$[28]$} \\
\hline Z. lotus stem & - & 0 & 33.80 & 0 & 24.40 & 21.73 & 11.10 & 0 & 0 & - & - & 0 & {$[28]$} \\
\hline Argan oil & - & 0.10 & 11.7 & 0.14 & 4.9 & 36.6 & 31.3 & 0.09 & 0.33 & 0.12 & - & 0.06 & {$[42]$} \\
\hline Cactus seed oil & - & - & 20.1 & 1.80 & 2.72 & 18.3 & 53.5 & 2.58 & - & - & - & - & {$[48]$} \\
\hline Olive oil & - & 11.5 & 0.9 & 1.4 & 61.9 & 3.8 & 1.1 & 0.23 & - & - & - & - & {$[41]$} \\
\hline Prickly pear peel & 0.71 & 1.95 & 23.1 & 2.48 & 2.67 & 24.1 & 32.3 & 9.27 & - & 0.5 & - & 0.41 & [49] \\
\hline Cactus cladodes & 1.33 & 1.96 & 13.87 & 0.24 & 3.33 & 11.16 & 34.87 & 33.23 & - & - & - & - & {$[50]$} \\
\hline Grape seed oil & - & 0.06 & 8.3 & 0.1 & 3 & 12 & 67.6 & 0.3 & 0.2 & 0.1 & 0.02 & 0.01 & {$[51]$} \\
\hline Sunflower oil & - & 0.08 & 7.4 & 0.09 & 4.56 & 25.17 & 60.15 & 0.3 & - & - & - & 0.34 & {$[52]$} \\
\hline Soybean oil & - & - & 6 & 0.4 & 2.2 & 26.1 & 50.1 & 14.5 & - & - & - & - & {$[43]$} \\
\hline Corn oil & - & - & 13.4 & traces & 1.5 & 27.4 & 56 & 0.9 & 0.2 & - & - & - & {$[44]$} \\
\hline R. stricta seed oil & - & $<0.01$ & 5.96 & 0.18 & 2.14 & 27.01 & 59.03 & 0.62 & 0.76 & 0.50 & 0.04 & 0.16 & {$[53]$} \\
\hline Z. jujuba pulp & 4.68 & 2.91 & 18.67 & 8.69 & 8.43 & 36.67 & 10.88 & 1.63 & 1.59 & 0.56 & - & - & {$[10]$} \\
\hline Z. zizyphus seed & - & 0.14 & 4.67 & 0.06 & 2.64 & 46.55 & 40.77 & 0.36 & 0.78 & 0.98 & - & - & [54] \\
\hline
\end{tabular}

TABLE 3: Composition of triacylglycerol (TAG) in Z. lotus seed oil; TAG contents are expressed as $\mathrm{g} / 100 \mathrm{~g}[11]$.

\begin{tabular}{lcc}
\hline $\begin{array}{l}\text { Triacylglycerol } \\
\text { Fatty acids attached }\end{array}$ & $\begin{array}{c}\text { Equivalent carbon } \\
\text { number }\end{array}$ & $\begin{array}{c}\text { Content in } \\
\text { g/100 g }\end{array}$ \\
\hline $\begin{array}{l}\text { Dipalmitic and oleic } \\
\text { acids }\end{array}$ & 48 & 2.87 \\
$\begin{array}{l}\text { Palmitic, oleic, and } \\
\text { stearic acids } \\
\text { Oleic and dilinoleic } \\
\text { acids }\end{array}$ & 50 & 4.69 \\
$\begin{array}{l}\text { Dioleic and linolenic } \\
\text { acids }\end{array}$ & 44 & 2.20 \\
$\begin{array}{l}\text { Palmitic and } \\
\text { dilinoleic acids }\end{array}$ & 44 & 6.23 \\
$\begin{array}{l}\text { Dioleic and linoleic } \\
\text { acids + Palmitoleic } \\
\text { and oleic acids } \\
\text { Palmitic, oleic, and } \\
\text { linoleic acids } \\
\begin{array}{l}\text { Dipalmitic and } \\
\text { linoleic acids }\end{array}\end{array}$ & 46 & 2.65 \\
$\begin{array}{l}\text { Trioleic acids } \\
\text { Palmitic and dioleic } \\
\text { acids }\end{array}$ & 46 & 16.32 \\
$\begin{array}{l}\text { Stearic and dioleic } \\
\text { acids }\end{array}$ & 46 & 9.28 \\
\hline
\end{tabular}

major amino acid in this part with $26.73 \%$ of total amino acid content, followed by glutamic acid (17.28\%), leucine $(13.11 \%)$, arginine $(9.47 \%)$, aspartic acid $(7.76 \%)$, and alanine $(4.56 \%)$
(Table 7). In Z. lotus seed, total proteins represent $14.22 \%$ higher than $Z$. lotus pulp with $1.18 \%$ [19]. But nowadays, amino composition of $Z$. lotus pulp remains to be elucidated.

\section{Traditional Uses of $Z$. lotus in Medicine, Nutrition, Health, and Disease}

4.1. Z. lotus in Ancestral Medicine. Several parts of Z. lotus have been used in traditional medicine for the treatment of bronchitis, diarrhea, and abscess [61]. In addition, the powder of dried leaves and fruit mixed with water or milk is used for the treatment of boils [62] and the root bark for the treatment of diabetes [16]. The juice from $Z$. lotus root would be efficient in the treatment of eye leucomas [63]. The fruits and the leaves of $Z$. lotus are used as emollient [61] and in the treatment of diarrhea and intestinal diseases [63].

4.2. Z. lotus in Nutrition. Z. lotus fruits would still be consumed by local population in North Africa. The fruits are dried and processed into flour to make pancakes with very pleasant flavor [64]. The nutritional virtue of $Z$. lotus is mainly based on its composition rich in vitamin E, vitamin C, fibers, fatty acids, amino acids, calcium, magnesium, and considerable amounts of sugars as mentioned above. The vegetable oils are widely consumed in our diet. They contribute to foods flavor, taste, and texture. Consistent with this, it has been reported that $Z$. lotus oil is of high quality, because of its content in unsaturated fatty acids and other bioactive compounds [11].

4.3. Z. lotus in Health and Disease. Traditional uses of Z. lotus have reported several benefits of this plant and its bioactive 
TABLE 4: Distribution and contents of vitamins in the different parts of $Z$. lotus. Vitamin contents are expressed as mg/100 g.

\begin{tabular}{|c|c|c|c|c|c|c|c|}
\hline & Leaves & Seeds & Root & Pulp & Stem & Fruit & Reported by \\
\hline Vitamin A & 13.52 & - & 6.45 & 71.63 & 3.8 & & \\
\hline Vitamin B2 & - & 0.08 & - & - & - & & \\
\hline Vitamin C & 63.40 & $31.24-170.84$ & 47.20 & 190.65 & 24.65 & 5.67 & \\
\hline Vitamin B1 & - & 0.03 & & - & - & 0.039 & \\
\hline Vitamin E & 155.71 & - & 4.7 & 11.23 & 4.5 & & \\
\hline Carotenoids & - & 0.634 & - & - & - & 1.47 & {$[11,28,55]$} \\
\hline$\alpha$-Tocopherol & - & - & - & - & - & - & \\
\hline$\beta$-Tocopherol & - & 130.47 & - & - & - & - & \\
\hline$\gamma$-Tocopherol & - & - & - & - & - & - & \\
\hline$\delta$-Tocopherol & - & 10.60 & - & - & - & - & \\
\hline Total tocopherols & & 141.07 & & & & 0.97 & \\
\hline
\end{tabular}

TABLE 5: Comparison of sterols composition of $Z$. lotus seed oil and other edible oils. Sterol contents are expressed in $\mathrm{mg} / 100 \mathrm{~g}$.

\begin{tabular}{|c|c|c|c|c|}
\hline Zizyphus species & Z. lotus & Z. jujuba & Z. zizyphus & References \\
\hline Cholesterol & 1.73 & - & 0.22 & \multirow{12}{*}[10,11,54]{} \\
\hline Campesterol & 31.89 & 2.4 & 19.24 & \\
\hline$\delta^{7}$-Campesterol & 147.82 & - & - & \\
\hline Stigmasterol & 16.38 & 4.69 & 27.32 & \\
\hline$\beta$-Sitosterol & 82.10 & 10.65 & 214.32 & \\
\hline$\delta^{5}$-Avenasterol & 0.57 & - & 10.41 & \\
\hline$\delta^{7}$-Stigmasterol & - & 0.82 & & \\
\hline$\Delta^{5}, 24$-Stigmatadienol & 4.45 & - & - & \\
\hline Cycloartenol & - & - & 14.15 & \\
\hline Methylene cycloartenol & - & - & 3.32 & \\
\hline Citrostadienol & - & - & 2.84 & \\
\hline Total sterols & 285.03 & 18.56 & 291.82 & \\
\hline
\end{tabular}

TABLE 6: Distribution and contents of minerals in the various parts of $Z$. lotus. Mineral contents are expressed as $\mathrm{mg} / 100 \mathrm{~g}$.

\begin{tabular}{lcccc}
\hline Major component & Seeds & Fruit & Pulp & Source \\
\hline Potassium & $92.41-97.92$ & 134.99 & 134.99 & \\
Calcium & 110.58 & 490.84 & - & \\
Magnesium & $153.92-1349.06$ & 397.91 & 397.91 & \\
Sodium & $7.30-17.41$ & - & 11.45 & \\
Iron & 1.21 & 1.33 & 1.33 & {$[11,19,55]$} \\
Manganese & 7.84 & 2.17 & 2.17 & \\
Zinc & 1.38 & 0.44 & 0.44 & \\
Copper & - & - & - & \\
Phosphorus & 24 & - & 10.62 & \\
\hline
\end{tabular}

compounds. Meantime, there has been a growing scientific data to support these beneficial properties of $Z$. lotus through several experimental models devoted to the assessment of $Z$. lotus natural molecules to cure numerous diseases. This plant is rich in polyphenols, flavonoids, tannins, alkaloids, and saponins which have several healthy properties like antidiabetic, hypoglycemic, and gastroprotective actions [21, 22]. As mentioned above, lotusine $B$, lotusine $C$, jujuboside
$A$, and jujuboside $C$ are the main active constituents of $Z$. lotus root bark (Table 1) and might exert antibacterial and antifungal activity $[65,66]$.

\section{Pharmacological and Biological Activities of Z. lotus Compounds}

Therapeutic benefits of $Z$. lotus compounds or extracts have been highlighted by several experimental models (cell and animal) through in vivo and in vitro studies.

5.1. Antioxidant and Anti-Inflammatory. Several studies report that the extracts of $Z$. lotus exhibit anti-inflammatory and antioxidant properties. As shown in Table $1, Z$. lotus is rich in many antioxidant compounds such as phenolic acids, flavonoids, alkaloids, and saponins. These components have been shown to prevent oxidative stress and inflammation by reducing reactive oxygen species (ROS) [69]. Interestingly, numerous in vitro studies have demonstrated the capacity of the different parts of $Z$. lotus for scavenging free radicals, for instance, in lipid peroxidation, resulting in cell damage prevention $[4,13,21,23,24,26]$. Moreover, in diabetic rats, the aqueous extract of $Z$. lotus roots and leaves strongly increases the rate of haemolysis and glutathione reductase and decreases catalase activity, glutathione peroxidase, and 
TABLE 7: Comparison of amino acids content in Z. lotus seeds and other plants. Amino acid contents are expressed as g/100 g.

\begin{tabular}{lcccc}
\hline Amino acids & $\begin{array}{c}\text { Z. lotus } \\
\text { seed }\end{array}$ & $\begin{array}{c}\text { Z. jujuba } \\
\text { seed }\end{array}$ & $\begin{array}{c}\text { O. } \\
\text { ficus-indica } \\
\text { seed }\end{array}$ & Source \\
\hline Isoleucine & 2.85 & 2.55 & 6.20 & \\
Leucine & 13.11 & 5.52 & 9.94 & \\
Lysine & 1.55 & 4.42 & 6.79 & \\
Glycine & 2.67 & 3.46 & 5.06 & \\
Phenylalanine & 2.65 & 2.82 & 5.25 & \\
Threonine & 26.73 & 30.98 & 1.53 & \\
Valine + Methionine & 1.80 & 4.05 & $0.7+6.02$ & [11, 67, 68] \\
Tryptophan & 1.36 & & trace & \\
Glutamic acid & 17.28 & 10.02 & 21.68 & \\
Aspartic acid & 7.76 & 6.38 & & \\
Tyrosine & 2.27 & 1.59 & 3.09 & \\
Serine + histidine + & 4.57 & 17 & 11.57 & \\
Glutamine & & & 4.75 & \\
Alanine & 4.56 & 4.23 & 6.63 & \\
Arginine & 9.47 & 2.87 & &
\end{tabular}

the status of antioxidant, suggesting that this plant corrected diabetes-induced antioxidant status [22]. Besides, the involvement of glutathione in protein and DNA synthesis, cellular detoxification, and inflammation has been reported [70]. For this reason, $Z$. lotus extract might have potential benefit for cellular protection. In vitro data on human $\mathrm{T}$ cells suggest that $Z$. lotus fruits have higher antioxidant activities compared to other parts of this plant, followed by leaves, root, and stem [28]. Furthermore, the secondary metabolites of $Z$. lotus administrated orally in carrageenan-induced rat paw edema presented anti-inflammatory effects in dosedependent manner [62] by inhibiting paw edema and the production of nitrite in lipopolysaccharide-activated RAW 264.7 macrophages without cytotoxicity [18]. These studies sustained that $Z$. lotus biomolecules might have beneficial effects for human health, for example, to reduce or prevent inflammation and oxidative damage.

5.2. Antimicrobial and Antifungal. In vitro studies have elucidated the effects of $Z$. lotus extracts on the growth of several bacteria and fungi species (see Table 8). They demonstrated that the extracts of $Z$. lotus fruits under etheric and methanolic solvents presented the most bactericidal effects to induce growth inhibition $[13,25]$. These antimicrobial activities of $Z$. lotus fruits seem to be mediated by phenolic compounds content in this part of $Z$. lotus as shown elsewhere [71]. Altogether, these reports provided evidence that $Z$. lotus with antibacterial effects might be considered as source of natural biomolecules for producing synthetic bactericides and fungicides.

5.3. Antidiabetic and Hypoglycemic. In a Wistar rat model of streptozotocin-induced hyperglycemia [72], hypoglycemic effects of $Z$. lotus indicate that the aqueous extracts of roots presented the most efficient activities compared to Z. lotus leaves [22]. This beneficial effect might be correlated with the high quantities of vitamin A observed in leaves and roots of $Z$. lotus. Indeed, it has been reported that insulin sensitivity was improved by vitamin A through activation of insulin receptor and protein tyrosine phosphatase 1B [73]. Moreover, lower amounts of vitamins were observed in diabetic animals compared to control animals [74].

5.4. Antiulcerogenic and Gastroprotective. Gastric ulcer is part of gastrointestinal disorder involving inflammation and default of defense mechanism. In many in vivo studies, protective effects of aqueous extracts of $Z$. lotus (root bark, leaves, and fruit) administered orally were observed in the lesions of several ulcerogenic induced models in Wistar rat $[21,27]$. These reports suggest that the extracts of this plant act as antiulcer agent by reducing gastric acidity and juice secretion. Helicobacter pylori is the most common bacterium that can survive in the highly acidic environment of the human stomach involving different digestive diseases such as peptic ulcer, dyspepsia (heartburn, acid indigestion, and nausea) [75, 76], the stomach cancer (adenocarcinoma) [77, 78], and MALT lymphoma [79]. Interestingly, the effect of methanol extract of $Z$. lotus (fruits) has been studied in vitro on 22 clinical strains of Helicobacter pylori, indicating that this plant has bactericidal effects on these clinical strains [21].

5.5. Analgesic and Antispasmodic. In Swiss mice, analgesic effects of aqueous extract of $Z$. lotus root barks were observed in a dose-dependent manner [62]. In acetic acid-induced algesia in mice, analgesic activities were also reported by flavonoid and saponin extracts from $Z$. lotus leaves and root bark in vivo, while in vitro, this effect is modulated by nitrite production in RAW 264.7 macrophages [18]. In addition, ex vivo studies on isolated rat duodenum show that aqueous extract of $Z$. lotus leaves and root bark exerts antispasmodic activities by modulating $\mathrm{Ca}^{2+}$ signaling via cholinergic receptors [32].

\section{Z. lotus Phenolic Compounds and Immune System: Mechanisms of Action}

Beneficial effects of $Z$. lotus polyphenols on health might be generated by their antioxidant and radical scavenging properties. Interestingly, our previous studies demonstrated that $Z$. lotus polyphenols also modulate human immune cell signaling and exert immunosuppressive effects [14]. As shown in Figure 3 , in human T cells, Z. lotus polyphenols (ZLP) upregulate thapsigargin- (TG-, inhibitor of $\mathrm{Ca}^{2+}$-ATPase) mediated calcium signaling at endoplasmic reticulum level, modulate plasma membrane, and, thus, block the entry of ions, decrease ERK1 and ERK2 activation, diminish cell proliferation and IL-2 expression by arresting $S$ cell cycle, and increase intracellular acidification in dose-dependent manner [14]. ZLP alone do not induce elevation of intracellular calcium concentration, $\left[\mathrm{Ca}^{2+}\right]_{i}$, in these cells. Consistent with this, $Z$. lotus might have a potential benefit in human autoimmune diseases. 
TABLE 8: Overview of major bioactive effects of $Z$. lotus preparations in different experimental models.

\begin{tabular}{|c|c|c|c|}
\hline Biological activity & Z. lotus part used & Experimental models & References \\
\hline \multirow{6}{*}{ Antioxidant } & $\begin{array}{l}\text { Z. lotus pulp, seed, leaf, root, and stem } \\
\text { extracts }\end{array}$ & In vitro studies in jurkat cells & \multirow{6}{*}[4,13,21-24,26,28]{} \\
\hline & Z. lotus fruits and root extracts & $\begin{array}{l}\text { Dpph radical and hydroxyl radical } \\
\text { scavenging activities }\end{array}$ & \\
\hline & Methanol extracts of $Z$. lotus leaf and fruit & $\begin{array}{l}\text { Dpph (2,2-diphenyl-1-picrylhydrazyl) } \\
\text { assay }\end{array}$ & \\
\hline & Z. lotus extracts from roots and leaves & $\begin{array}{l}\text { In vivo studies in wistar rats pancreas, } \\
\text { liver, and erythrocytes. }\end{array}$ & \\
\hline & $\begin{array}{l}\text { Hydroalcoholic extracts of } Z \text {. lotus leaves } \\
\text { and fruits }\end{array}$ & Lipid peroxidation, dpph & \\
\hline & Z. lotus (fruits) methanol extract & Free radical (dpph) scavenging test & \\
\hline \multirow{3}{*}{ Antimicrobial } & \multirow[t]{2}{*}{ Methanol extracts of leaves and fruits } & $\begin{array}{l}\text { In vitro studies in Gram-negative } \\
\text { bacteria: Escherichia coli atcc } 8739 \text {, } \\
\text { Salmonella typhimurium nctc } 6017 \text {, } \\
\text { Aeromonas hydrophila ei, and } \\
\text { Pseudomonas aeruginosa atcc } 27853\end{array}$ & \multirow{3}{*}[13,25]{} \\
\hline & & $\begin{array}{l}\text { In vitro studies in Gram-positive bacteria: } \\
\text { Staphylococcus aureus atcc } 29213 \text {, Listeria } \\
\text { monocytogenes atcc } 7644 \text {, and Bacillus } \\
\text { cereus atcc } 1247\end{array}$ & \\
\hline & $\begin{array}{l}\text { Etheric, dichlorométhanic, and } \\
\text { methanolic extracts of fruit and its active } \\
\text { compounds (phenols, flavonoids, and } \\
\text { tannins) }\end{array}$ & $\begin{array}{l}\text { In vitro studies in bacterial species: } \\
\text { Bacillus subtilis, Bacillus cereus, } \\
\text { Escherichia coli, Klebsiella pneumoniae, } \\
\text { Salmonella typhi, Staphylococcus aureus, } \\
\text { Enterococcus faecalis, and Pseudomonas } \\
\text { aeruginosa }\end{array}$ & \\
\hline \multirow[b]{2}{*}{ Antifungal } & Methanol extracts of leaves and fruits & $\begin{array}{l}\text { In vitro studies: Aspergillus flavus and } \\
\text { Aspergillus niger }\end{array}$ & \multirow[b]{2}{*}[13,25]{} \\
\hline & $\begin{array}{l}\text { Etheric, dichlorométhanic, methanolic, } \\
\text { and difenoconazole extracts of fruit }\end{array}$ & $\begin{array}{l}\text { Fungal species: Penicillium italicum, } \\
\text { Fusarium culmorum, Aspergillus } \\
\text { ochraceus, and Rhizomucor sp }\end{array}$ & \\
\hline Anticandidal & Methanol extracts of leaves and fruits & In vitro studies: candida albicans & [13] \\
\hline immunosuppressive & $\begin{array}{l}\text { Polyphenols from } Z \text {. lotus fruit } \\
\text { pulp, seed, leaf, root, and stem extracts }\end{array}$ & $\begin{array}{l}\text { In vitro studies: human t cells } \\
\text { In vitro studies: jurkat cells }\end{array}$ & {$[14,28]$} \\
\hline \multirow{3}{*}{ Anti-inflammatory } & $\begin{array}{l}\text { Flavonoid and saponin from root bark } \\
\text { and leaves of } Z \text {. lotus }\end{array}$ & $\begin{array}{l}\text { In vivo studies in wistar rats and swiss } \\
\text { albino mice } \\
\text { In vitro studies in raw } 264.7 \text { macrophages }\end{array}$ & \multirow{3}{*}[18,26,62]{} \\
\hline & $\begin{array}{l}\text { Methanolic extracts of root bark and } \\
\text { leaves of } Z \text {. lotus }\end{array}$ & In vivo studies in mice & \\
\hline & $\begin{array}{l}\text { Hydroalcoholic extracts of } Z \text {. lotus leaves } \\
\text { and fruits }\end{array}$ & Lipoxygenase assay & \\
\hline Analgesic & $\begin{array}{l}\text { Flavonoid and saponin from root bark } \\
\text { and leaves of } Z \text {. lotus }\end{array}$ & $\begin{array}{l}\text { In vivo studies in wistar rats and swiss } \\
\text { albino mice }\end{array}$ & {$[18,62]$} \\
\hline \multirow[t]{2}{*}{ Antiulcerogenic } & $\begin{array}{l}\text { Aqueous, methanolic, ethyl acetate, and } \\
\text { chloroformic extracts of } Z \text {. lotus root } \\
\text { barks, leaves, and fruit }\end{array}$ & In vivo studies in wistar rats & \multirow[t]{2}{*}[21,27]{} \\
\hline & Z. lotus (fruits) methanol extract & In vivo studies in wistar rats & \\
\hline Antispasmodic & $\begin{array}{l}\text { Aqueous and methanolic extracts of } Z \text {. } \\
\text { lotus leaves and root barks }\end{array}$ & Ex vivo studies on isolated rat duodenum & {$[32]$} \\
\hline Antidiabetic & $\begin{array}{l}Z \text {. lotus aqueous extracts from roots and } \\
\text { leaves }\end{array}$ & $\begin{array}{l}\text { In vivo studies in diabetic wistar rats } \\
\text { pancreas, liver, and erythrocytes. }\end{array}$ & {$[22]$} \\
\hline Hypoglycemic & $\begin{array}{l}\text { Aqueous extract of leaf and root from } Z \text {. } \\
\text { lotus }\end{array}$ & In vivo studies in wistar rats & [22] \\
\hline \multirow[b]{2}{*}{ Gastroprotective } & \multirow{2}{*}{ Z. lotus (fruits) methanol extract } & In vivo studies in wistar rats & \multirow[b]{2}{*}[21]{} \\
\hline & & $\begin{array}{l}\text { In vitro studies in } 22 \text { clinical strains of } \\
\text { helicobacter pylori j99 }\end{array}$ & \\
\hline
\end{tabular}




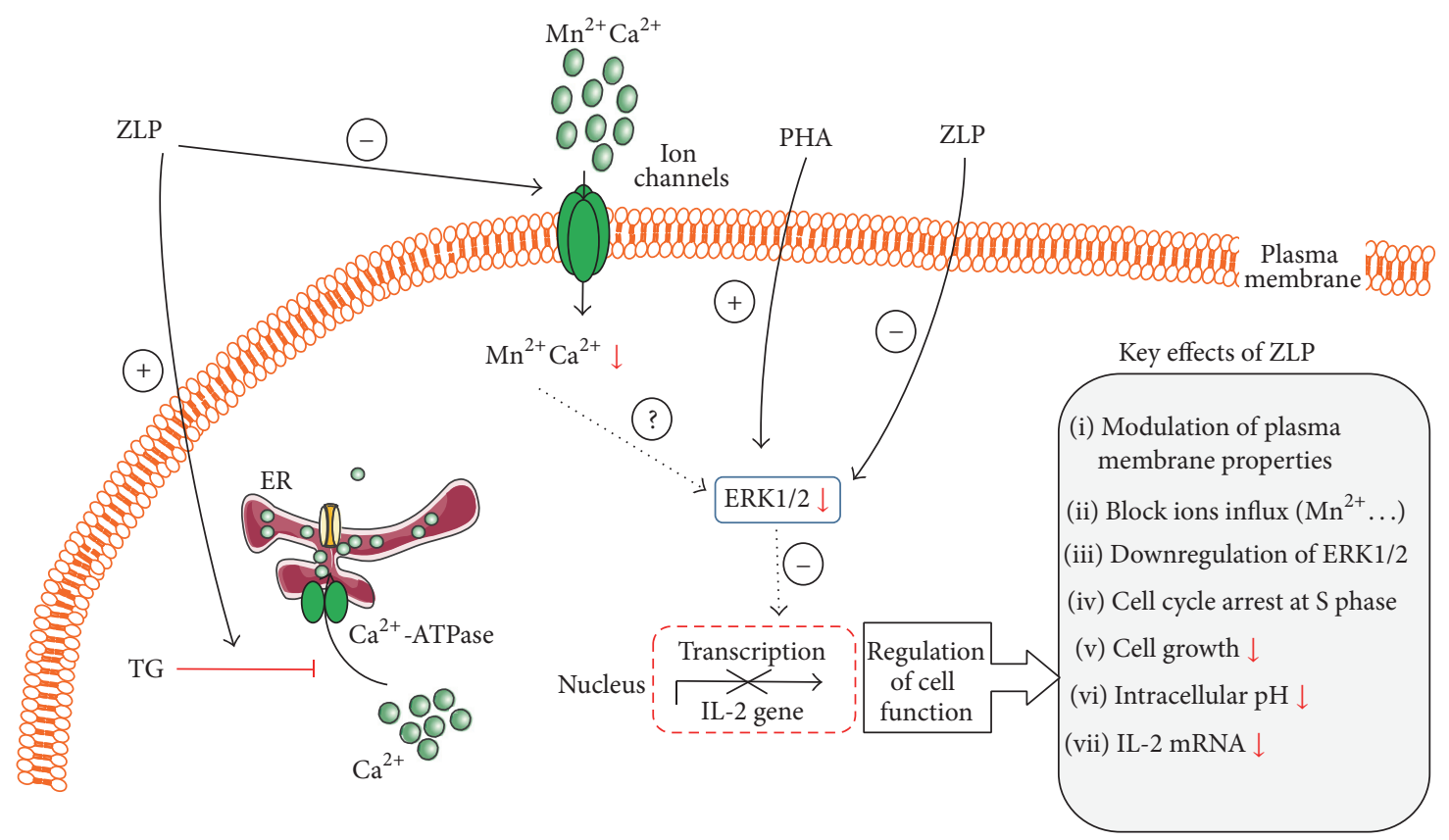

Figure 3: Schematic representation of Z. Lotus phenolic compounds-induced immune cell signaling. Note: ZLP: Z. Lotus polyphenols; TG: Thapsigargin; PHA: phytohemagglutinin (see text for details).

\section{Conclusion}

Collectively, this review provides updated comprehensive information on $Z$. lotus as a source of several bioactive compounds which hold therapeutic potentialities for human nutrition, health promoting, and disease preventing. As mentioned in Table 8, several scientific papers have clearly reported many biological properties of the different parts of this plant and its constituents through in vitro and in vivo studies. The potent antioxidant, antimicrobial, and antiinflammatory effects of $Z$. lotus have been distinctly elucidated. On another side, $Z$. lotus extracts present beneficial effects on metabolic disorders via antidiabetic and hypoglycemic actions. In vivo studies showed that Z. lotus supplementation might be used to treat gastrointestinal disorders. On the nutritional level, this plant is rich in many nutriments which may be used in various fields such as food, cosmetics, and pharmaceutics.

\section{Future Perspectives}

Although several studies reported the benefit effects of $Z$. lotus in many facets of human nutrition, health, and disease, the exact mechanisms by which $Z$. lotus bioactive compounds exert their biological and pharmacological activities are not yet entirely elucidated.

Therefore, further studies are required to elucidate the effects of $Z$. lotus extracts and active compounds in some unexplored domains such as cancer, metabolic disorders, inflammation, and age-linked diseases as well as their mechanisms of actions.

\author{
Abbreviations \\ Z. Lotus: Zizyphus lotus \\ ZLP: Zizyphus lotus polyphenols \\ TG: Thapsigargin \\ PHA: Phytohemagglutinin \\ $\left[\mathrm{Ca}^{2+}\right]_{i}$ : Intracellular calcium concentration \\ IL-2: Interleukin-2 \\ ERK1/2: Extracellular signal-regulated kinase 1/2 \\ ER: Endoplasmic reticulum.
}

\section{Competing Interests}

The author has no potential conflict of interests to declare.

\section{Acknowledgments}

This work was supported by grants from the French Ministry of Higher Education and Research.

\section{References}

[1] M. Maraghni, M. Gorai, and M. Neffati, "Seed germination at different temperatures and water stress levels, and seedling emergence from different depths of Ziziphus lotus," South African Journal of Botany, vol. 76, no. 3, pp. 453-459, 2010.

[2] J. E. Richardson, L. W. Chatrou, J. B. Mols, R. H. J. Erkens, and M. D. Pirie, "Historical biogeography of two cosmopolitan families of flowering plants: annonaceae and rhamnaceae," Philosophical Transactions of the Royal Society B: Biological Sciences, vol. 359, no. 1450, pp. 1495-1508, 2004. 
[3] M. Gorai, M. Maraghni, and M. Neffati, “TPED Relationship between phenological traits and water potential patterns of the wild jujube Ziziphus lotus (L.) Lam. in southern Tunisia," Plant Ecology and Diversity, vol. 3, no. 3, pp. 273-280, 2010.

[4] M. Adeli and V. Samavati, "Studies on the steady shear flow behavior and chemical properties of water-soluble polysaccharide from Ziziphus lotus fruit," International Journal of Biological Macromolecules, vol. 72, pp. 580-587, 2015.

[5] A. G. Pottier, Flora of Tunisia Angiospermes-Dicotyledones, Apetales-Dialypetales. Programme Flore et Végétation Tunisiennes, Ministère de l'Enseignement Supérieur et de la Recherche Scientifique et le Ministère de l'Agriculture, Tunis, Tunisia, 1981.

[6] B. Adzu, S. Amos, M. B. Amizan, and K. Gamaniel, "Evaluation of the antidiarrhoeal effects of Zizyphus spina-christi stem bark in rats," Acta Tropica, vol. 87, no. 2, pp. 245-250, 2003.

[7] M. Lahlou, M. El Mahi, and J. Hamamouchi, "Evaluation of antifungal and molluscicidal activities of Moroccan Zizyphus lotus (L.) Desf," Annales Pharmaceutiques Francaises, vol. 60, no. 6, pp. 410-414, 2002.

[8] E. Le-Floc'h, Contribution à une Étude Ethnobotanique de la Flore de la Tunisie: Programme Flore et Végétation Tunisienne, Publications Scientifiques Tunisiennes, 1983.

[9] K. K. Anand, B. Singh, D. Grand, B. K. Chandan, and V. N. Gupta, "Effect of Zizyphus sativa leaves on blood glucose levels in normal and alloxan-diabetic rats," Journal of Ethnopharmacology, vol. 27, no. 1-2, pp. 121-127, 1989.

[10] M. Elaloui, A. Laamouri, A. Albouchi et al., "Chemical compositions of the tunisian Ziziphus jujuba oil," Emirates Journal of Food and Agriculture, vol. 26, no. 7, pp. 602-608, 2014.

[11] M. Chouaibi, N. Mahfoudhi, L. Rezig, F. Donsì, G. Ferrari, and S. Hamdi, "Nutritional composition of Zizyphus lotus L. seeds," Journal of the Science of Food and Agriculture, vol. 92, no. 6, pp. 1171-1177, 2012.

[12] J.-H. Renault, K. Ghedira, P. Thepenier, C. Lavaud, M. ZechesHanrot, and L. Le Men-Olivier, "Dammarane saponins from Zizyphus lotus," Phytochemistry, vol. 44, no. 7, pp. 1321-1327, 1997.

[13] H. Ghazghazi, C. Aouadhi, L. Riahi, A. Maaroufi, and B. Hasnaoui, "Fatty acids composition of Tunisian Ziziphus lotus L. (Desf.) fruits and variation in biological activities between leaf and fruit extracts," Natural Product Research, vol. 28, no. 14, pp. 1106-1110, 2014.

[14] S. Abdoul-Azize, M. Bendahmane, A. Hichami et al., "Effects of Zizyphus lotus L. (Desf.) polyphenols on Jurkat cell signaling and proliferation," International Immunopharmacology, vol. 15, no. 2, pp. 364-371, 2013.

[15] K. Ghedira, R. Chemli, B. Richard, J.-M. Nuzillard, M. Zeches, and L. Le Men-Olivier, "Two cyclopeptide alkaloids from Zizyphus lotus," Phytochemistry, vol. 32, no. 6, pp. 1591-1594, 1993.

[16] K. Ghedira, R. Chemli, C. Caron, J.-M. Nuzilard, M. Zeches, and L. Le Men-Olivier, "Four cyclopeptide alkaloids from Zizyphus lotus," Phytochemistry, vol. 38, no. 3, pp. 767-772, 1995.

[17] G. Le Crouéour, P. Thépenier, B. Richard, C. Petermann, K. Ghédira, and M. Zèches-Hanrot, "Lotusine G: a new cyclopeptide alkaloid from Zizyphus lotus," Fitoterapia, vol. 73, no. 1, pp. 63-68, 2002.

[18] W. Borgi, M.-C. Recio, J. L. Ríos, and N. Chouchane, "Antiinflammatory and analgesic activities of flavonoid and saponin fractions from Zizyphus lotus (L.) Lam.," South African Journal of Botany, vol. 74, no. 2, pp. 320-324, 2008.
[19] M. Abdeddaim, O. Lombarkia, A. Bacha et al., "Biochemical characterization and nutritional properties of Zizyphus lotus 1 . fruits in aures region, northeastern of Algeria," Food Science and Technology, vol. 15, pp. 75-81, 2014.

[20] A. Maciuk, C. Lavaud, P. Thépenier, M.-J. Jacquier, K. Ghédira, and M. Zèches-Hanrot, "Four new dammarane saponins from Zizyphus lotus," Journal of Natural Products, vol. 67, no. 10, pp. 1639-1643, 2004.

[21] F.-Z. Bakhtaoui, H. Lakmichi, F. Megraud, A. Chait, and C.-E. A. Gadhi, "Gastro-protective, anti-Helicobacter pylori and, antioxidant properties of Moroccan Zizyphus lotus L," Journal of Applied Pharmaceutical Science, vol. 4, no. 10, pp. 81-87, 2014.

[22] C. Benammar, C. Baghdad, M. Belarbi, S. Subramaniam, A. Hichami, and N. A. Khan, "Antidiabetic and antioxidant activities of Zizyphus lotus L aqueous extracts in Wistar rats," Journal of Nutrition \& Food Sciences, 2014.

[23] K. M. Hammi, A. Jdey, C. Abdelly, H. Majdoub, and R. Ksouri, "Optimization of ultrasound-assisted extraction of antioxidant compounds from Tunisian Zizyphus lotus fruits using response surface methodology," Food Chemistry, vol. 184, pp. 80-89, 2015.

[24] M. Ghalem, S. Merghache, and M. Belarbi, "Study on the antioxidant activities of root extracts of Zizyphus lotus from the western region of Algeria," Pharmacognosy Journal, vol. 6, no. 4, pp. 32-42, 2014.

[25] N. Rsaissi, EL Kamili, B. Bencharki, L. Hillali, and M. Bouhache, "Antimicrobial activity of fruits extracts of the wild jujube 'Ziziphus Lotus (L.) Desf.,' International Journal of Scientific \& Engineering Research, vol. 4, pp. 1521-1528, 2013.

[26] B. Boulanouar, G. Abdelaziz, S. Aazza, C. Gago, and M. G. Miguel, "Antioxidant activities of eight Algerian plant extracts and two essential oils," Industrial Crops and Products, vol. 46, pp. 85-96, 2013.

[27] B. Wahida, B. Abderrahman, and C. Nabil, "Antiulcerogenic activity of Zizyphus lotus (L.) extracts," Journal of Ethnopharmacology, vol. 112, no. 2, pp. 228-231, 2007.

[28] C. Benammar, A. Hichami, A. Yessoufou et al., “Zizyphus lotus L. (Desf.) modulates antioxidant activity and human T-cell proliferation," BMC Complementary and Alternative Medicine, vol. 10, article 54, 2010.

[29] A. Maciuk, K. Ghedira, P. Thepenier, C. Lavaud, and M. ZechesHanrot, "A new flavonol glycoside from leaves of Zizyphus lotus," Pharmazie, vol. 58, no. 2, pp. 158-159, 2003.

[30] F. Benkhalti, J. Prost, E. Paz, F. Perez-Jimenez, C. El Modafar, and E. El Boustani, "Effects of feeding virgin olive oil or their polyphenols on lipid of rat liver," Nutrition Research, vol. 22, no. 9, pp. 1067-1075, 2002.

[31] H. Tapiero, K. D. Tew, G. Nguyen Ba, and G. Mathé, “Polyphenols: do they play a role in the prevention of human pathologies?" Biomedicine and Pharmacotherapy, vol. 56, no. 4, pp. 200207, 2002.

[32] W. Borgi and N. Chouchane, "Anti-spasmodic effects of Zizyphus lotus (L.) Desf. extracts on isolated rat duodenum," Journal of Ethnopharmacology, vol. 126, no. 3, pp. 571-573, 2009.

[33] B. A. Sutherland, R. M. A. Rahman, and I. Appleton, "Mechanisms of action of green tea catechins, with a focus on ischemia-induced neurodegeneration," Journal of Nutritional Biochemistry, vol. 17, no. 5, pp. 291-306, 2006.

[34] R. Leenen, A. J. C. Roodenburg, L. B. M. Tijburg, and S. A. Wiseman, "A single dose of tea with or without milk increases plasma antioxidant activity in humans," European Journal of Clinical Nutrition, vol. 54, no. 1, pp. 87-92, 2000. 
[35] J. Martinez and J. J. Moreno, "Effect of resveratrol, a natural polyphenolic compound, on reactive oxygen species and prostaglandin production," Biochemical Pharmacology, vol. 59, no. 7, pp. $865-870,2000$.

[36] J. Bajerska, M. Wozniewicz, J. Jeszka, S. Drzymala-Czyz, and J. Walkowiak, "Green tea aqueous extract reduces visceral fat and decreases protein availability in rats fed with a high-fat diet," Nutrition Research, vol. 31, no. 2, pp. 157-164, 2011.

[37] N. Ahmad, P. Cheng, and H. Mukhtar, "Cell cycle dysregulation by green tea polyphenol epigallocatechin-3-gallate," Biochemical and Biophysical Research Communications, vol. 275, no. 2, pp. 328-334, 2000.

[38] F. Ren, S. Zhang, S. H. Mitchell, R. Butler, and C. Y. F. Young, "Tea polyphenols down-regulate the expression of the androgen receptor in LNCaP prostate cancer cells," Oncogene, vol. 19, no. 15, pp. 1924-1932, 2000.

[39] Y.-C. Liang, S.-Y. Lin-Shiau, C.-F. Chen, and J.-K. Lin, "Suppression of extracellular signals and cell proliferation through EGF receptor binding by (-)-epigallocatechin gallate in human A431 epidermoid carcinoma cells," Journal of Cellular Biochemistry, vol. 67, no. 1, pp. 55-65, 1997.

[40] D. O. Kennedy, S. Nishimura, T. Hasuma, Y. Yano, S. Otani, and I. Matsui-Yuasa, "Involvement of protein tyrosine phosphorylation in the effect of green tea polyphenols on Ehrlich ascites tumor cells in vitro," Chemico-Biological Interactions, vol. 110, no. 3, pp. 159-172, 1998.

[41] D. Ollivier, J. Artaud, C. Pinatel, J. P. Durbec, and M. Guérère, "Triacylglycerol and fatty acid compositions of French virgin olive oils. Characterization by chemometrics," Journal of Agricultural and Food Chemistry, vol. 51, no. 19, pp. 5723-5731, 2003.

[42] R. Marfil, C. Cabrera-Vique, R. Giménez, P. R. Bouzas, O. Martínez, and J. A. Sánchez, "Metal content and physicochemical parameters used as quality criteria in virgin argan oil: influence of the extraction method," Journal of Agricultural and Food Chemistry, vol. 56, no. 16, pp. 7279-7284, 2008.

[43] F. O. Ayorinde, K. Garvin, and K. Saeed, "Determination of the fatty acid composition of saponified vegetable oils using matrix-assisted laser desorption/ionization time-of-flight mass spectrometry," Rapid Communications in Mass Spectrometry, vol. 14, no. 7, pp. 608-615, 2000.

[44] I. J. Karoui, W. A. Wannes, and B. Marzouk, "Refined corn oil aromatization by Citrus aurantium peel essential oil," Industrial Crops and Products, vol. 32, no. 3, pp. 202-207, 2010.

[45] J. J. Ochoa, J. L. Quiles, M. C. Ramírez-Tortosa, J. Mataix, and J. R. Huertas, "Dietary oils high in oleic acid but with different unsaponifiable fraction contents have different effects in fatty acid composition and peroxidation in rabbit LDL," Nutrition, vol. 18, no. 1, pp. 60-65, 2002.

[46] B. Aspenström-Fagerlund, J. Tallkvist, N.-G. Ilbäck, and A. W. Glynn, "Oleic acid increases intestinal absorption of the BCRP/ABCG2 substrate, mitoxantrone, in mice," Toxicology Letters, vol. 237, no. 2, pp. 133-139, 2015.

[47] S. M. Soel, O. S. Choi, M. H. Bang, J. H. Yoon Park, and W. K. Kim, "Influence of conjugated linoleic acid isomers on the metastasis of colon cancer cells in vitro and in vivo," Journal of Nutritional Biochemistry, vol. 18, no. 10, pp. 650-657, 2007.

[48] M. F. Ramadan and J.-T. Moersel, "Lipid profile of prickly pear pulp fractions," Journal of Food, Agriculture and Environment, vol. 1, pp. 66-70, 2003.

[49] M. F. Ramadan and J.-T. Mörsel, "Oil cactus pear (Opuntia ficus-indica L.)," Food Chemistry, vol. 82, no. 3, pp. 339-345, 2003.
[50] S. Abidi, H. Ben Salem, V. Vasta, and A. Priolo, "Supplementation with barley or spineless cactus (Opuntia ficus indica $f$. inermis) cladodes on digestion, growth and intramuscular fatty acid composition in sheep and goats receiving oaten hay," Small Ruminant Research, vol. 87, no. 1-3, pp. 9-16, 2009.

[51] M. Rubio, M. Alvarez-Ortí, A. S. Alvarruiz, E. Fernández, and J. E. Pardo, "Characterization of oil obtained from grape seeds collected during berry development," Journal of Agricultural and Food Chemistry, vol. 57, no. 7, pp. 2812-2815, 2009.

[52] S. Filip, J. Hribar, and R. Vidrih, "Influence of natural antioxidants on the formation of trans-fatty-acid isomers during heat treatment of sunflower oil," European Journal of Lipid Science and Technology, vol. 113, no. 2, pp. 224-230, 2011.

[53] I. A. Nehdi, H. M. Sbihi, C. P. Tan, and S. I. Al-Resayes, "Seed oil from Harmal (Rhazya stricta Decne) grown in Riyadh (Saudi Arabia): a potential source of $\delta$-tocopherol," Journal of Saudi Chemical Society, vol. 20, no. 1, pp. 107-113, 2016.

[54] M. El Aloui, K. Mguis, A. Laamouri et al., "Fatty acid and sterol oil composition of four Tunisian ecotypes of Ziziphus zizyphus (L.) H.Karst," Acta Botanica Gallica, vol. 159, no. 1, pp. 25-31, 2012.

[55] S. Boudraa, L. Hambaba, S. Zidani, and H. Boudraa, "Mineral and vitamin composition of fruits of five underexploited species in Algeria: Celtis australis L., Crataegus azarolus L., Crataegus monogyna Jacq., Elaeagnus angustifolia L. and Zizyphus lotus L," Fruits, vol. 65, no. 2, pp. 75-84, 2010.

[56] W. E. Neff, T. L. Mounts, W. M. Rinsch, and H. Konishi, "Photooxidation of soybean oils as affected by triacylglycerol composition and structure," Journal of the American Oil Chemists' Society, vol. 70, no. 2, pp. 163-168, 1993.

[57] W. E. Neff, T. L. Mounts, W. M. Rinsch, H. Konishi, and M. A. El-Agaimy, "Oxidative stability of purified canola oil triacylglycerols with altered fatty acid compositions as affected by triacylglycerol composition and structure," Journal of the American Oil Chemists' Society, vol. 71, no. 10, pp. 1101-1109, 1994.

[58] F. Ntanios, "Plant sterol-ester-enriched spreads as an example of a new functional food," European Journal of Lipid Science and Technology, vol. 103, no. 2, pp. 102-106, 2001.

[59] M. D. Salvador, F. Aranda, S. Gómez-Alonso, and G. Fregapane, "Cornicabra virgin olive oil: a study of five crop seasons. Composition, quality and oxidative stability," Food Chemistry, vol. 74, no. 3, pp. 267-274, 2001.

[60] M. Guderjan, S. Tôpfl, A. Angersbach, and D. Knorr, "Impact of pulsed electric field treatment on the recovery and quality of plant oils," Journal of Food Engineering, vol. 67, no. 3, pp. 281287, 2005.

[61] J. Bellakhdar, La Pharmacopée Marocaine Traditionnelle, Ibis Press, Paris, France, 1997.

[62] W. Borgi, K. Ghedira, and N. Chouchane, "Antiinflammatory and analgesic activities of Zizyphus lotus root barks," Fitoterapia, vol. 78, no. 1, pp. 16-19, 2007.

[63] K. Boukef, Les Plantes Dans la Médicine Traditionnelle Tunisienne: Medicine Traditionnelle et Pharmacopée, Agence de Coopération Culturelle et Technique, Paris, France, 1986.

[64] K. Ghedira, "Zizyphus lotus (L.) Desf. (Rhamnaceae): jujubier sauvage," Phytothérapie, vol. 11, no. 3, pp. 149-153, 2013.

[65] T. A. Van Beek, A. M. Deelder, R. Verpoorte, and A. Baerheim Svendsen, "Antimicrobial, antiamoebic and antiviral screening of some Tabernaemontana species," Planta Medica, vol. 50, no. 2, pp. 180-185, 1984. 
[66] V. B. Pandey and S. Devi, "Biologically active cyclopeptide alkaloids from Rhamnaceae plants," Planta Medica, vol. 56, no. 6, pp. 649-650, 1990.

[67] J.-W. Li, L.-P. Fan, S.-D. Ding, and X.-L. Ding, "Nutritional composition of five cultivars of Chinese jujube," Food Chemistry, vol. 103, no. 2, pp. 454-460, 2007.

[68] W. N. Sawaya, J. K. Khalil, and M. M. Al-Mohammad, "Nutritive value of prickly pear seeds, Opuntia ficus-indica," Plant Foods for Human Nutrition, vol. 33, no. 1, pp. 91-97, 1983.

[69] R. A. A. Mothana, "Anti-inflammatory, antinociceptive and antioxidant activities of the endemic Soqotraen Boswellia elongata Balf. f. and Jatropha unicostata Balf. f. in different experimental models," Food and Chemical Toxicology, vol. 49, no. 10, pp. 2594-2599, 2011.

[70] L. A. S. Brown, F. L. Harris, X.-D. Ping, and T. W. Gauthier, "Chronic ethanol ingestion and the risk of acute lung injury: a role for glutathione availability?" Alcohol, vol. 33, no. 3, pp. 191-197, 2004.

[71] N. H. Aziz, S. E. Farag, L. A. A. Mousa, and M. A. Abo-Zaid, "Comparative antibacterial and antifungal effects of some phenolic compounds," Microbios, vol. 93, no. 374, pp. 43-54, 1998.

[72] A. O. Abdel-Zaher, S. Y. Salim, M. H. Assaf, and R. H. AbdelHady, "Antidiabetic activity and toxicity of Zizyphus spinachristi leaves," Journal of Ethnopharmacology, vol. 101, no. 1-3, pp. 129-138, 2005.

[73] S. M. Jeyakumar, P. Vijaya Kumar, N. V. Giridharan, and A. Vajreswari, "Vitamin A improves insulin sensitivity by increasing insulin receptor phosphorylation through protein tyrosine phosphatase $1 \mathrm{~B}$ regulation at early age in obese rats of WNIN/Ob strain," Diabetes, Obesity and Metabolism, vol. 13, no. 10, pp. 955-958, 2011.

[74] R. K. Sundaram, A. Bhaskar, S. Vijayalingam, M. Viswanathan, R. Mohan, and K. R. Shanmugasundaram, "Antioxidant status and lipid peroxidation in type II diabetes mellitus with and without complications," Clinical Science, vol. 90, no. 4, pp. 255260, 1996.

[75] M. Shadman, Z. Rajabian, A. Ajami et al., "Frequency of $\gamma \delta \mathrm{T}$ cells and invariant natural killer T cells in Helicobacter pyloriinfected patients with peptic ulcer and gastric cancer," Iranian Journal of Allergy, Asthma and Immunology, vol. 14, no. 5, pp. 493-501, 2015.

[76] A. M. Costa, R. M. Ferreira, I. Pinto-Ribeiro et al., "Helicobacter pylori activates matrix metalloproteinase-10 in gastric epithelial cells via EGFR and ERK-mediated pathways," Journal of Infectious Diseases, vol. 213, no. 11, pp. 1767-1776, 2016.

[77] C. Zhang, H. Yu, H. Xu, and L. Yang, "Expression of secreted phospholipase A2-Group IIA correlates with prognosis of gastric adenocarcinoma," Oncology Letters, vol. 10, no. 5, pp. 3050-3058, 2015.

[78] M. Fassan, D. Saraggi, L. Balsamo et al., "Let-7c down-regulation in Helicobacter pylori-related gastric carcinogenesis," Oncotarget, vol. 7, no. 4, pp. 4915-4924, 2016.

[79] R. Yuge, Y. Kitadai, S. Tanaka et al., "Regression of cecal MALT lymphoma after antibiotic treatment in a patient with Helicobacter pylori infection," Internal Medicine, vol. 55, no. 2, pp. 135-139, 2016. 


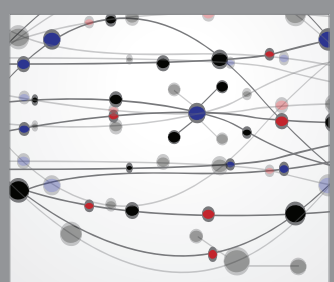

The Scientific World Journal
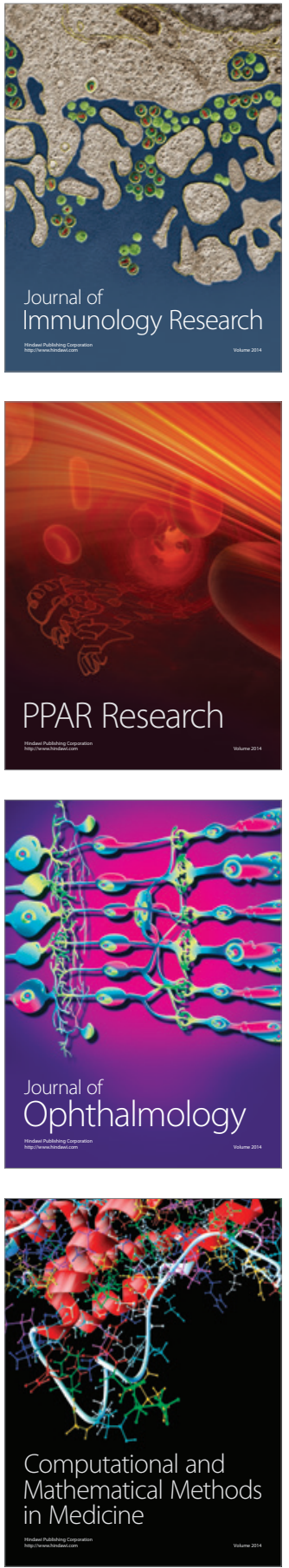

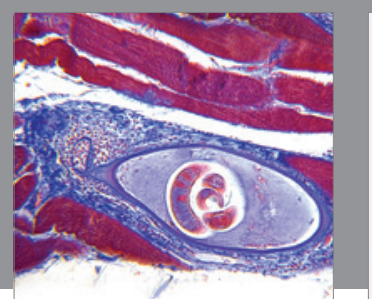

Gastroenterology Research and Practice

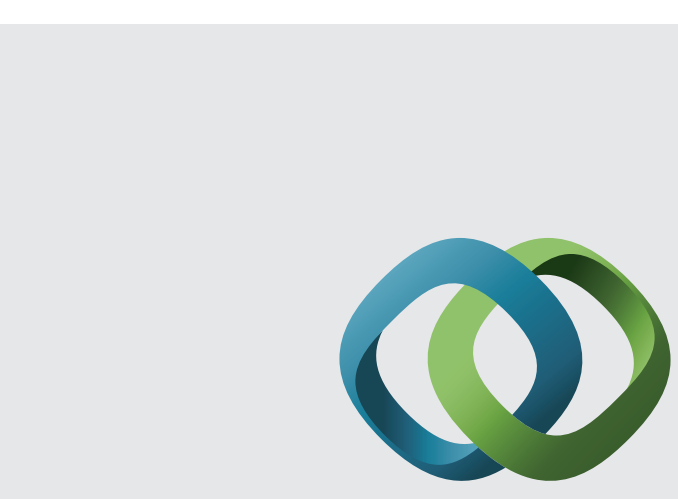

\section{Hindawi}

Submit your manuscripts at

http://www.hindawi.com
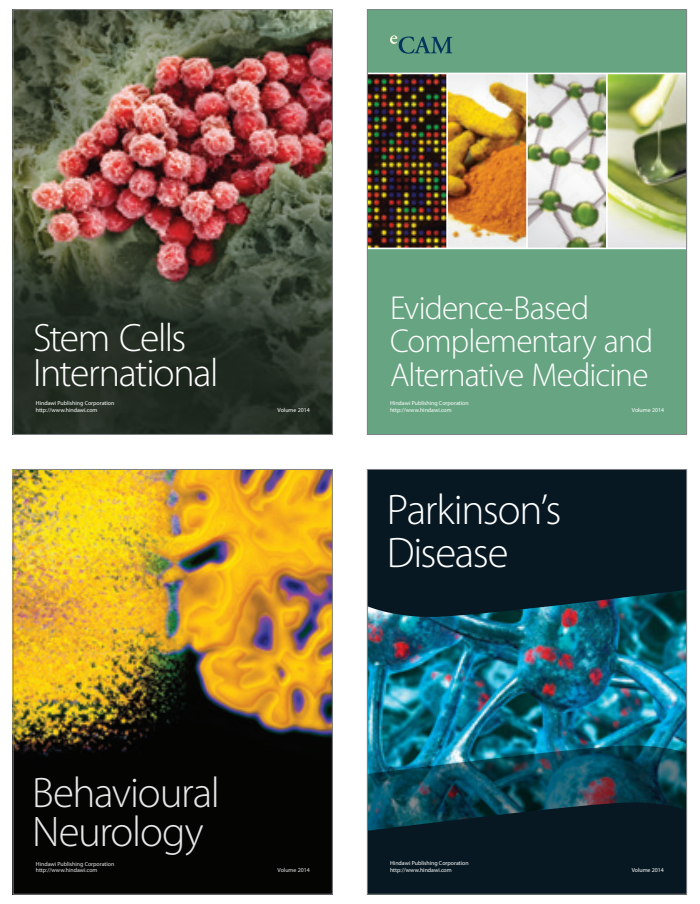
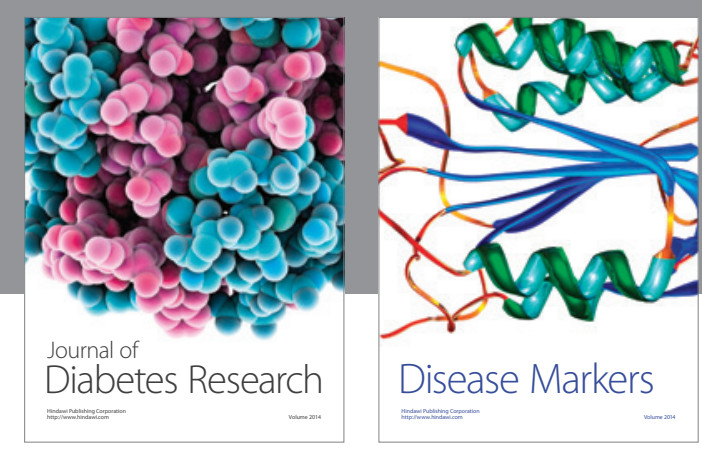

Disease Markers
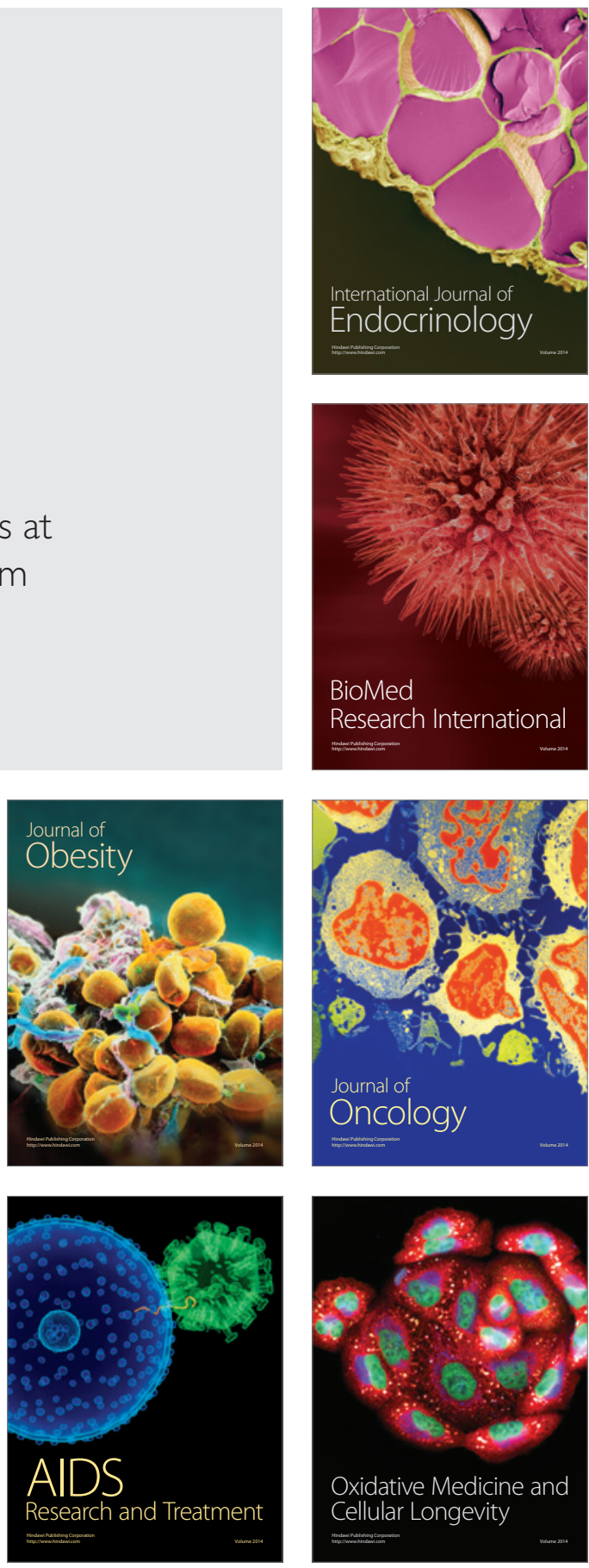